\title{
Novel Corrosion Inhibitor for Mild Steel in Simulated Concrete Pore Solution with Chloride Contamination
}

\author{
S. BALASUBRAMANIYAN*, S.MOHAN and M.VISHNUDEVAN \\ Department of Chemistry, Govt. Arts College (Autonomous), Karur- 639 005, India \\ balasubramaniyanchem@gmail.com
}

Received 6 September 2014 / Accepted 25 September 2014

\begin{abstract}
The corrosion resistance performance of mild steel in simulated concrete pore solution $(\mathrm{pH}>12$ ) containing a) $0.5 \mathrm{M}$ sodium Nitrite b) $0.2 \mathrm{M}$ sodium citrate c) $0.4 \mathrm{M}$ sodium benzoate inhibitors in $0.5 \mathrm{M} \mathrm{NaCl}$ solution contamination were evaluated by electrochemical studies. The observed inhibition efficiencies were compared with gravimetric method after 30 days of immersion, for inhibited and uninhibited system. The maximum inhibition efficiency of $0.5 \mathrm{M}$ sodium nitrite $+0.2 \mathrm{M}$ sodium citrate $+0.4 \mathrm{M}$ sodium benzoate mixed inhibitor system was found to be $75 \%$. The inhibition efficiencies for the mixed inhibitor system were compared with control and single inhibitor system. From these study it was found that the role of nitrite ion present in the mixed inhibitor system repassivated the mild steel that drastically reduce the corrosion rate even in presence of high chloride concentration.
\end{abstract}

Keywords: Inhibitor, Inhibition efficiency, Chloride, Mild steel, Corrosion rate

\section{Introduction}

Rebar corrosion problem in reinforced concrete structure facing a serious threat due to deterioration of concrete structures due to; 1 ) Ingress of chloride near mild steel that reduce $\mathrm{pH}$ and destruct the passive layer, 2) Sulphate attack which causes concrete deterioration due to ettringite formation. Several researches are ongoing to mitigate this rebar corrosion problem due to ingress of chloride and sulphate attack on concrete leads to spallation. These studies are simulating rebar corrosion in concrete structure exposed to industrial and marine environment.

Valek et al. have studied ${ }^{1}$ inhibition performance of mild steel in ascorbic acid in alkaline medium. The inhibition performance of ascorbic acid were analysed through polarization study. The study revealed that the inhibitor protect the mild steel cathodically. Ameer et al. have studied ${ }^{2}$ inhibition performance of mild steel in organic inhibitors in alkaline medium. The results from potentiodynamic polarization showed that the observed corrosion current density $\mathrm{I}_{\text {corr }}$, decreases with increasing the concentration of organic inhibitors indicating a decrease in the corrosion rate as well as an increase in the inhibition efficiency of mild steel. Electrochemical impedance spectroscopy measurements and SEM confirmed this behaviour. Further the study revealed that the organic inhibitors protect the mild steel cathodically. 
Florica and Co-workers have investigated ${ }^{3}$ Inhibition performance of mild steel in phosphate coated steel by cathodic electrochemical treatment in alkaline medium. The inhibition performance of zinc phosphate coated steel were analysed through conducting potentiodyanamic polarization and electrochemical impedance studies, the above study revealed that the inhibitor protect steel surface effectively when compared to uninhibited mild steel rebar.

Ameer et al. $^{2}$ have studied inhibitor performance of mild steel in heterocyclic organic compounds in chloride contaminated alkaline medium. The inhibitions performance of heterocyclic compounds were analysed through conducting electrochemical study. The study revealed that the inhibitor protect the mild steel. The inhibition efficiency increase adsorption of inhibitor on steel surface. Nahali et al. ${ }^{4}$ have studied the inhibition performance of mild steel in phosphate containing chloride contaminated alkaline medium. The inhibition performance of phosphate were assessed by electrochemical measurements and morphological studies were done to characterise the corrosion product using SEM and XRD.

Similar studies were reported ${ }^{5-17}$ for mid steel corrosion in chloride contaminated alkaline medium by electrochemical studies and the inhibitors repassivated the steel surface and reduce the pitting corrosion. The present work is also focused on the evaluation of corrosion resistance performance novel inhibitor for mild steel corrosion in chloride contaminated alkaline solution.

\section{Experimental}

The corrosion behaviour of mild steel in chloride contaminated concrete pore solution of $0.5 \mathrm{M}$ $\mathrm{Ca}(\mathrm{OH})_{2}+0.1 \mathrm{M} \mathrm{NaOH}+0.3 \mathrm{M} \mathrm{KOH}$ containing the following inhibitor formulations $0.5 \mathrm{M}$ sodium nitrite, $0.2 \mathrm{M}$ sodium citrate, $0.4 \mathrm{M}$ sodium benzoate were evaluated by (i) gravimetric method (ii) Tafel polarization method and (iii) electrochemical impedance spectroscopic method. $0.5 \mathrm{M} \mathrm{NaCl}$ solution was used to accelerate the corrosion rate of mild steel. The exposure period of mild the present in the investigation are 15 days and 30 days. Polished, degreased mild steel specimens with an area of $7 \mathrm{~cm}^{2}$ along with a duplicate specimens were immersed in chloride contaminated concrete pore solutions containing with and without inhibitors. The following are the system studied to evaluate the corrosion behaviour of mild steel containing various inhibitor compositions:

a) Control: concrete pore solution containing $0.5 \mathrm{M} \mathrm{Ca}(\mathrm{OH})_{2}, 0.1 \mathrm{M} \mathrm{NaOH}$ and $0.3 \mathrm{M}$ $\mathrm{KOH}+0.5 \mathrm{M} \mathrm{NaCl}$ solution.

b) Control+ $0.5 \mathrm{M}$ Sodium nitrite solution.

c) Control+0.5 M Sodium nitrite $+0.2 \mathrm{M}$ Sodium citrate solution

d) Control+0.5 M Sodium nitrite+0.2 M sodium citrate+0.4 M sodium benzoate solution.

\section{Gravimetric method}

The initial weight of the mild steel specimens was noted along with duplicate specimens for with and without inhibitors added system. The weight loss measurements were carried out after 15 days and 30 days of exposure. After completion of 15 days and 30 days of immersion the mild steel specimens were taken out, cleaned in Clarks solution (con $\mathrm{HCl}+$ antimony trioxide $\left(\mathrm{Sb}_{2} \mathrm{O}_{3}\right) 20 \mathrm{~g}+$ stannous chloride $\left.\left(\mathrm{SnCl}_{2}\right) 50 \mathrm{~g}\right)$ and finally rinsed with distilled water, air dried and then the final weight was noted. From the weight loss, the corrosion rate in millimeter per year (mmpy) was calculated.

Corrosion rate $(\mathrm{mmpy})=87.6 \mathrm{xW} / \mathrm{DAT}$

Where, $\mathrm{W}=$ Weight loss (mg), D =Density of mild steel specimens $\left(\mathrm{g} / \mathrm{cm}^{3}\right), \mathrm{A}=$ Area of mild steel specimens $\left(\mathrm{cm}^{2}\right), \mathrm{T}=$ Exposure time $(\mathrm{h})$. The inhibition efficiency is calculated from the measured corrosion rate value and tabulated. 
Inhibition efficiency added $=\frac{\text { corrosion rate of control system }- \text { corrosion rate of inhibitor }}{\text { Corrosion rate of control system }}$ Tafel polarization method

Polished mild steel specimens of an exposure area $\left(1 \mathrm{~cm}^{2}\right)$ was subjected to potentiodynamic polarization with scan rate of $1 \mathrm{~m} \mathrm{~V} / \mathrm{sec}$ and $\pm 200 \mathrm{mV}$ away from open circuit potential value for with and without inhibitor added systems.

The potentiodynamic cell system consist of three electrodes; of these $1 \mathrm{~cm}^{2}$ area of mild steel specimen served as working electrode, $2 \mathrm{~cm}^{2}$ area of platinum foil served as counter electrode and saturated calomel electrode served as reference electrode. The experiments was carried out after 30 days of exposure of mild steel in chloride contaminated concrete pore solution containing with and without inhibitors added system. From the Tafel polarization curves $\mathrm{E}_{\text {corr }}, \mathrm{I}_{\text {corr }}$, ba,bc values were recorded and finally the corrosion rate (mmpy) was calculated from the following formula.

$$
\text { Corrosion rate }(\mathrm{mmpy})=3.2 \times \mathrm{I}_{\text {corr }}\left(\mathrm{mA} / \mathrm{cm}^{2}\right) \times \text { Eq.wt } / \text { Density }
$$

From the calculated corrosion rate value the Inhibition Efficiency was calculated and tabulated, finally the corrosion behaviour of mild steel in inhibitor added system were assessed.

\section{Electrochemical impedance spectroscopic technique}

Polished mild steel specimens of an exposure area of $1 \mathrm{~cm}^{2}$ was subject to AC impedance study with AC voltage in the range of $15 \mathrm{mv}$ and the frequency in the range of $10 \mathrm{MHz}-100$ $\mathrm{kHz}$ for with and without inhibitor added system. The AC-impedance study were conducted for all the system using three electrode cell systems as in Tafel polarization study.

The impedance behaviour for various inhibitor system were obtained in terms of Nyquiste plot (Figure $4 \& 5$ ). From the plots, change transfer resistance $\left(\mathrm{R}_{\mathrm{t}}\right)$, corrosion rate (mmpy) and inhibition efficiency (\%) values were calculated. Corrosion current $\mathrm{I}_{\text {corr }}$ can be evaluated from $\left(\mathrm{R}_{\mathrm{t}}\right)$ using Stern Geary equation.

$$
\mathrm{I}_{\text {corr }}=\mathrm{b}_{\mathrm{a}} \mathrm{b}_{\mathrm{c}} / 2.303\left(\mathrm{~b}_{\mathrm{a}}+\mathrm{b}_{\mathrm{c}}\right) \times 1 / \mathrm{Rt}=\mathrm{K} / \mathrm{Rt}
$$

Where, $\mathrm{b}_{\mathrm{a}}=$ anodic Tafel slope, $\mathrm{b}_{\mathrm{c}}=$ cathodic Tafel slope, Corrosion rate $=3.2 \mathrm{x}$ $\mathrm{I}_{\mathrm{Corr}}\left(\mathrm{mA} / \mathrm{cm}^{2}\right) \times$ equivalent weight/density.

\section{Surface morphological study by FTIR}

FTIR studies were carried out for the corroded samples to characterise the nature of corrosion product appeared on the mild steel surface and understand the mechanism of corrosion protection.

\section{Results and Discussion}

\section{Inhibition efficiency of gravimetric method}

The inhibition efficiencies were calculated for control and various inhibitors added systems of mild steel in chloride contaminated concrete pore solution and reported in Table 1 and represented in Figure 1. From the Table, it was inferred that in the case of control the passivity is heavily destroyed by aggressive chloride ions as indicated by the corrosion rate data. It was noted that all the inhibitors initially (after 15 days) showed inhibition efficiency below $45 \%$ but after 30 days of exposure, only the mixed inhibitors system (nitrite + citrate + benzoate) containing nitrite as one of the inhibitor maintained the passivity even in presence of high chloride concentration. 
Table 1. Measurement of corrosion rate of mild steel after 15 days and 30 days of exposure period of time by gravimetric method

\begin{tabular}{|c|c|c|c|c|}
\hline Systems studied & $\begin{array}{c}\text { Period of } \\
\text { immersion, days }\end{array}$ & $\begin{array}{l}\text { Weight loss, } \\
\text { mg }\end{array}$ & $\begin{array}{c}\text { Corrosion rate, } \\
\text { mmpy }\end{array}$ & $\begin{array}{c}\text { Inhibition } \\
\text { efficiency, \% }\end{array}$ \\
\hline \multirow{2}{*}{ Control } & 15 & 0.003 & 0.00663 & - \\
\hline & 30 & 0.016 & 0.03531 & - \\
\hline \multirow{2}{*}{$\begin{array}{l}\text { Control+ } 0.5 \mathrm{M} \\
\text { sodium nitrite }\end{array}$} & 15 & 0.002 & 0.00442 & 33 \\
\hline & 30 & 0.005 & 0.01103 & 69 \\
\hline \multirow{2}{*}{$\begin{array}{l}\text { Control+ } 0.5 \mathrm{M} \\
\text { sodium nitrite+ } 0.2 \mathrm{M} \\
\text { sodium citrate }\end{array}$} & 15 & 0.002 & 0.00442 & 33 \\
\hline & 30 & 0.010 & 0.0220 & 37 \\
\hline \multirow{2}{*}{$\begin{array}{l}\text { Control+0.5M sodium } \\
\text { nitrite+ } 0.2 \mathrm{M} \text { sodium } \\
\text { citrate+ } 0.4 \mathrm{M} \text { sodium } \\
\text { benzoate }\end{array}$} & 15 & 0.001 & 0.00221 & 43 \\
\hline & 30 & 0.004 & 0.00883 & 75 \\
\hline \multicolumn{5}{|l|}{100} \\
\hline 50 & & & Inhibition 15 days & \\
\hline $\mathrm{CO}_{\mathrm{Nit}}^{\mathrm{L}}$ & $\begin{array}{l}\text { Control + Sod. } \\
\text { Nitrate + Sod. } \\
\text { Citrate }\end{array}$ & $\begin{array}{l}\text { Control + Sod. Nitrate } \\
+ \text { Sod. Citrate + Sod. } \\
\text { benzoate }\end{array}$ & Inhibition 30 days & \\
\hline
\end{tabular}

Figure 1. Inhibition efficiency of control and various inhibitors systems of exposure periods 15 and 30 days by gravimetric method

\section{Potentiodynamic polarization (Tafel)}

$\mathrm{I}_{\text {corr }}\left(\mathrm{mA} / \mathrm{cm}^{2}\right)$, corrosion rate (mmpy) and inhibition efficiency (\%) calculated for various inhibitive systems were reported in Table 2 and shown in Figure 2 \& 3. From the table it was observed that for 15 days and 30 days exposures of mild steel in chloride contaminated concrete pore solution showed that nitrite ion maintained. Nitrite maintained stable passivity even after 30 days of exposure. In the case of mixed inhibitor systems the $I_{\text {corr }}\left(\mathrm{mA} / \mathrm{cm}^{2}\right)$ values showed that the systems maintained perfect passivity even after 30 days of exposure and an excellent passivation was observed in the case of control+ $0.5 \mathrm{M}$ sodium nitrite+ 0.2 M sodium citrate+ $0.4 \mathrm{M}$ sodium benzoate inhibitive systems.

\section{Electrochemical impedance spectroscopic technique}

Polarization resistance $\mathrm{R}_{\mathrm{ct}}(\mathrm{K} \Omega)$, corrosion rate (mmpy) and inhibition efficiency (\%) were calculated for control and various inhibitors added system in mild steel exposed to concrete pore solution after 30 days of exposure and were reported in Table 3 . The measured $R_{c t}$ value for control system was $1.755 \mathrm{~K} \Omega$ and the measured $\mathrm{R}_{\mathrm{ct}}$ value for control $+0.5 \mathrm{M}$ sodium nitrite was $1.768 \mathrm{~K} \Omega$, the measured $\mathrm{R}_{\mathrm{ct}}$ value for control $+0.5 \mathrm{M}$ sodium nitrite $+0.2 \mathrm{M}$ sodium citrate was $1.760 \mathrm{~K} \Omega$ and the $\mathrm{R}_{\mathrm{ct}}$ values for mixed inhibitors system was $3.229 \mathrm{~K} \Omega$. The inhibition efficiencies calculated for (i) Control (simulated concrete pore solution $+0.5 \mathrm{M} \mathrm{NaCl}$ ), (ii) Control+ $0.5 \mathrm{M}$ sodium nitrite, (iii) Control+0.5 M sodium nitrite $+0.2 \mathrm{M}$ sodium citrate and (iv) Control $+0.5 \mathrm{M}$ sodium nitrite $+0.2 \mathrm{M}$ sodium citrate $+0.4 \mathrm{M}$ sodium benzoate were found to be $15 \%, 20 \%$, 48\% respectively. It is observed that $\approx 2$ times increase in $\mathrm{R}_{\mathrm{ct}}$ value for mixed inhibitors $\left(4^{\text {th }}\right.$ system $)$ in comparison with control $\left(1^{\text {st }}\right.$ system $)$, Control $+0.5 \mathrm{M}$ sodium nitrite, $\left(2^{\text {nd }}\right.$ system $)$ and Control $+0.5 \mathrm{M}$ sodium nitrite $+0.2 \mathrm{M}$ sodium citrate ( $3^{\text {rd }}$ system). 
Among these the mixed inhibitors system showed the highest inhibition efficiencies, this was due to the synergistic action of nitrite with citrate and benzoate inhibitive systems.

Table 2. Measurement of corrosion rate of mild steel in chloride contaminated concrete pore solution containing with and without inhibitors after 30 days of exposure by Tafel polarization method

\begin{tabular}{|c|c|c|c|c|c|c|c|}
\hline Systems studied & $\begin{array}{c}\text { Period of } \\
\text { immersion, days }\end{array}$ & $\mathrm{b}_{\mathrm{a}}$ & $\mathrm{b}_{\mathrm{c}}$ & $\begin{array}{l}\text { OCP mV } \\
\text { vs. SCE }\end{array}$ & $\begin{array}{c}\mathrm{I}_{\text {corr }} \\
\mathrm{mA} / \mathrm{cm}^{2}\end{array}$ & $\begin{array}{c}\mathrm{C}_{\text {rate }} \\
\text { mmpy }\end{array}$ & $\begin{array}{c}\text { Inhibition } \\
\text { efficiency, \% }\end{array}$ \\
\hline Control & 30 & 8.275 & 4.936 & -0.44 & 4.286 & 0.0974 & - \\
\hline $\begin{array}{l}\text { Control+ } 0.5 \mathrm{M} \\
\text { sodium nitrite }\end{array}$ & 30 & 8.300 & 4.855 & -0.35 & 4.190 & 0.0877 & $30 \%$ \\
\hline $\begin{array}{l}\text { Control+0.5 M } \\
\text { sodium } \\
\text { nitrite+0.2 M } \\
\text { sodium citrate }\end{array}$ & 30 & 8.360 & 4.770 & -0.28 & 4.175 & 0.0750 & $25 \%$ \\
\hline $\begin{array}{l}\text { Control }+0.5 \mathrm{M} \\
\text { sodium nitrite+ } \\
0.2 \mathrm{M} \text { sodium } \\
\text { citrate }+0.4 \mathrm{M} \\
\text { sodium benzoate }\end{array}$ & 30 & 8.637 & 3.865 & -0.48 & 1.552 & 0.0353 & $64 \%$ \\
\hline
\end{tabular}
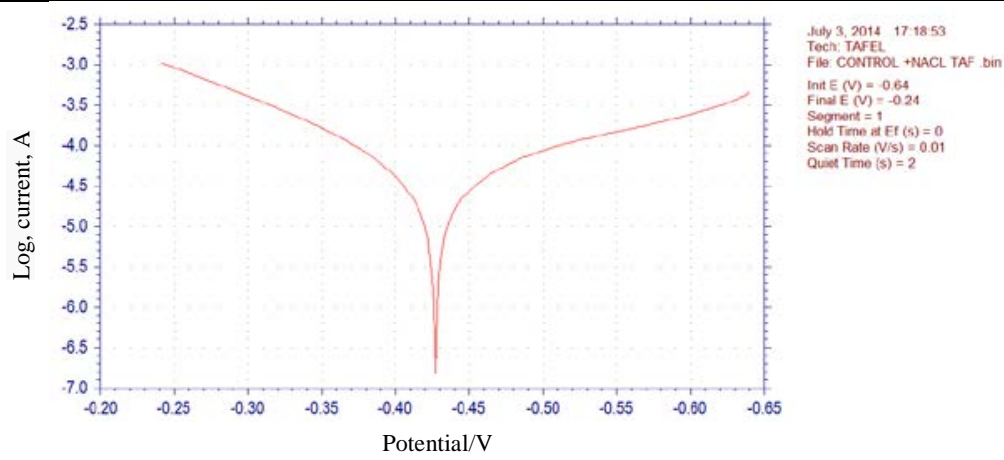

Figure 2. Tafel plot of mild steel specimens exposed to chloride contaminated concrete pore solution after 30 days of exposure
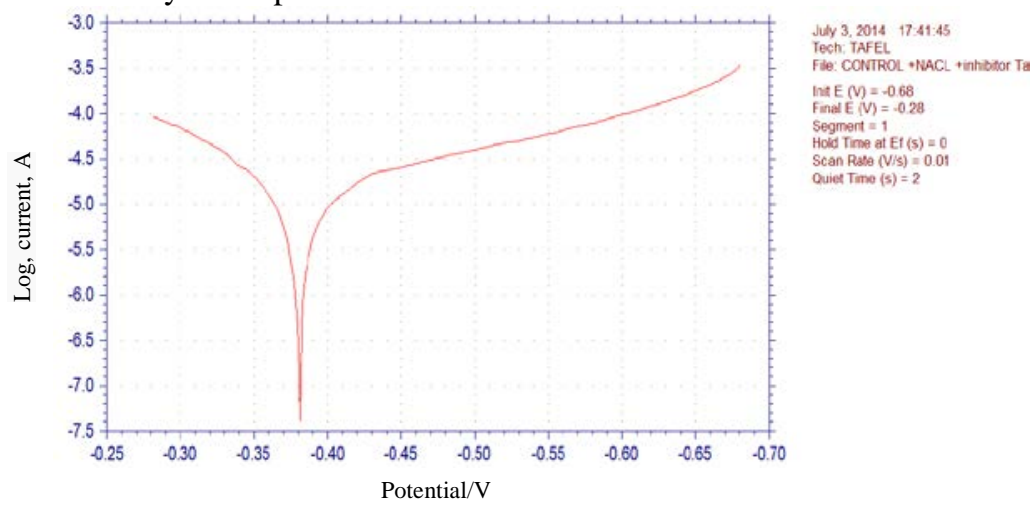

Figure 3. Tafel plot of mild steel specimens exposed to chloride contaminated concrete pore solution containing mixed inhibitors after 30 days of exposure 




July 3, $2014 \quad 17: 25: 34$ Tech: IMP

File: CONTROL +NACL IMPEDANC

$\ln \mathrm{E}(\mathrm{V})=-0.36$

High Freq $(\mathrm{Hz})=10+5$

Low Freq $(\mathrm{Hz})=$

Amplitude $(V)=0.005$

Quiet Tme (s) $=2$

Figure 4. Nyquiste plot of mild steel specimens exposed to chloride contaminated concrete pore solution after 30 days

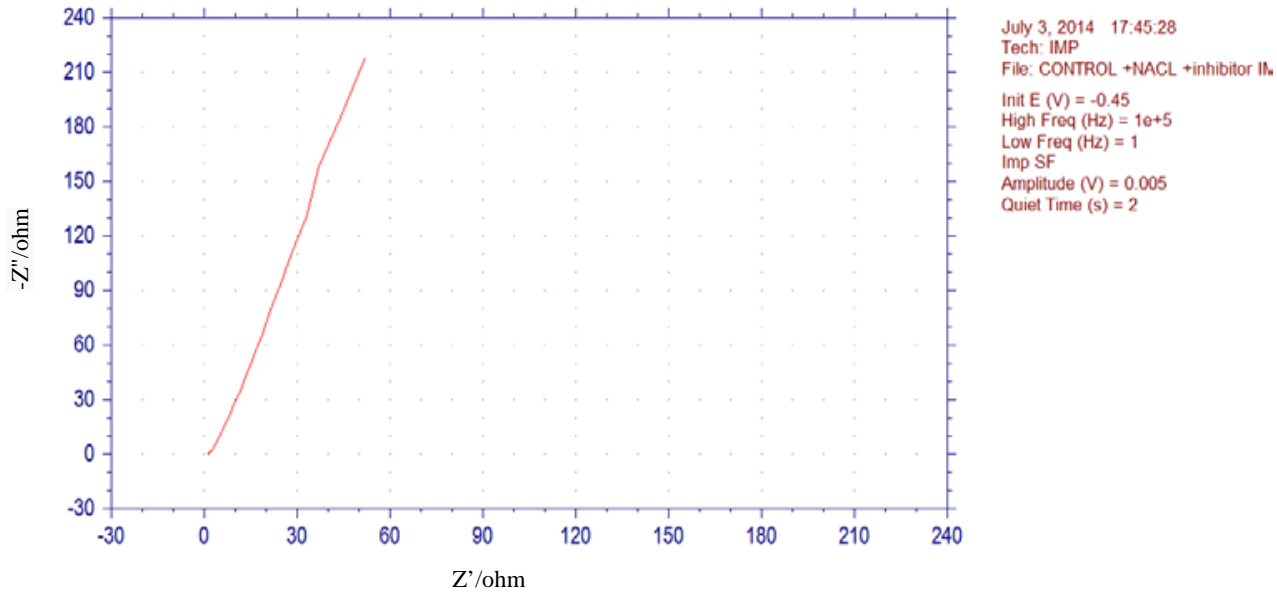

Figure 5. Nyquiste plot of mild steel specimens exposed to chloride contaminated concrete pore solution containing mixed inhibitors after 30 days

Table 3. Electrochemical impedance spectroscopic technique

\begin{tabular}{lccccc}
\hline Systems studied & $\begin{array}{c}\text { Period of } \\
\text { immersion, } \\
\text { (days) }\end{array}$ & $\begin{array}{c}\mathrm{R}_{\mathrm{ct}} \\
\mathrm{K} \Omega\end{array}$ & $\begin{array}{c}\mathrm{I}_{\text {corr }} \\
\mathrm{mA} / \mathrm{cm}^{2}\end{array}$ & $\begin{array}{c}\text { Corrosion } \\
\text { rate, mmpy }\end{array}$ & $\begin{array}{c}\text { Inhibition } \\
\text { efficiency } \\
\%\end{array}$ \\
\hline $\begin{array}{l}\text { Control } \\
\begin{array}{l}\text { Control+0.5 M } \\
\text { sodium nitrite }\end{array}\end{array}$ & 30 & 1.755 & 0.7036 & 0.0160 & - \\
$\begin{array}{l}\text { Control+0.5 M } \\
\text { sodium nitrite+0.2 M } \\
\text { sodium citrate }\end{array}$ & 30 & 1.768 & 0.8020 & 0.0230 & $15.00 \%$ \\
$\begin{array}{l}\text { Control+0.5 M } \\
\text { sodium nitrite+0.2 M } \\
\text { sodium citrate+0.4 M }\end{array}$ & 30 & 1.760 & 0.8015 & 0.0225 & $20.00 \%$ \\
sodium benzoate & & & & & \\
\hline
\end{tabular}


Comparison study of corrosion rate of mild steel exposed to chloride contaminated concrete pore solution containing with and without inhibitors

The corrosion rate in millimetre per years measured in all the studies were represented in Figure 6. From the figure it is observed that similar trends is observed in corrosion resistance performance of these inhibitors on mild steel corrosion for all the techniques studied such as gravimetric, Tafel polarisation and AC-impedance technique. From these data it is confirmed that the role of nitrite on mild steel corrosion is very significant. Further the mixed inhibitor containing nitrite as one of the inhibitor significantly reduce corrosion rate synergistically; i.e inner layer containing $\gamma \mathrm{Fe}_{2} \mathrm{O}_{3}$ followed by the chemisorptions of benzoate and citrate.

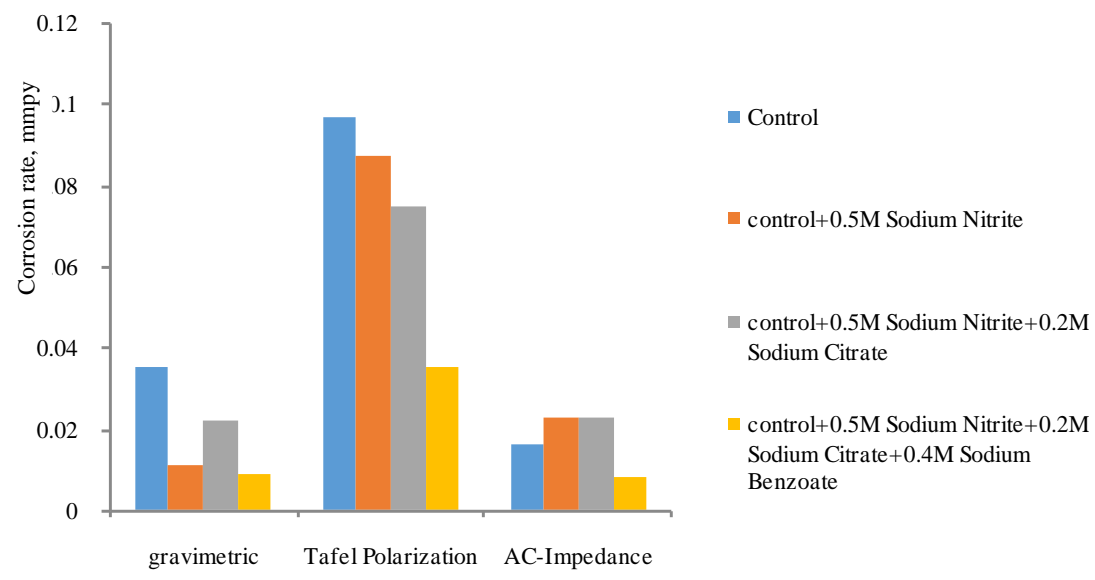

Figure 6. Comparison study of corrosion rate of mild steel observed in all the techniques Surface morphological study by FT-IR

FTIR studies were carried out for the samples in order to characterise the nature of corrosion product appeared on the mild steel surface and understand the mechanism of corrosion protection of this mixed inhibitors. FT-IR spectrum shown in the Figure 7 \& 8 , from the figure it is predicted that the peak between $400-700 \mathrm{~cm}^{-1}$ corresponds to Fe$\mathrm{O}$ bonds. The peak $462 \mathrm{~cm}^{-1}$ and $424 \mathrm{~cm}^{-1}$ appeared in the spectrum represents the presence of gamma iron oxide. The peak in the range $1760-1690 \mathrm{~cm}^{-1}$ and $1320-1210$ $\mathrm{cm}^{-1}$ corresponds to $\mathrm{C}=\mathrm{O}$ and $\mathrm{C}-\mathrm{O}$ Stretching respectively. The peaks $1328 \mathrm{~cm}^{-1}, 1346$ $\mathrm{cm}^{-1}$ and1739 $\mathrm{cm}^{-1}$ appeared in the spectrum predicts the presence of Carboxyl groups. The peak at $1560 \mathrm{~cm}^{-1}$ represents the presence of aromatic group and the peak at 1707 $\mathrm{cm}^{-1}$ confirm the presence of citrate.

From the above study it is confirmed that the following corrosion product; $\gamma \mathrm{Fe}_{2} \mathrm{O}_{3}$, aromatic carboxyl group and citrate. This confirmation on the mechanism of inhibitor over mild steel corrosion in chloride contaminated concrete pore solution gives the following conclusion; The destruction of passive film due to chloride ion over mild steel is again repassivated by the mixed inhibitors. The mechanism of these inhibitors is under synergistic action i.e firstly the nitrite inhibitor oxidise the steel to $\gamma \mathrm{Fe}_{2} \mathrm{O}_{3}$ followed by the chemisorptions of sodium benzoate and citrate over steel surface protects the mild steel beyond $\gamma \mathrm{Fe}_{2} \mathrm{O}_{3}$ film. 


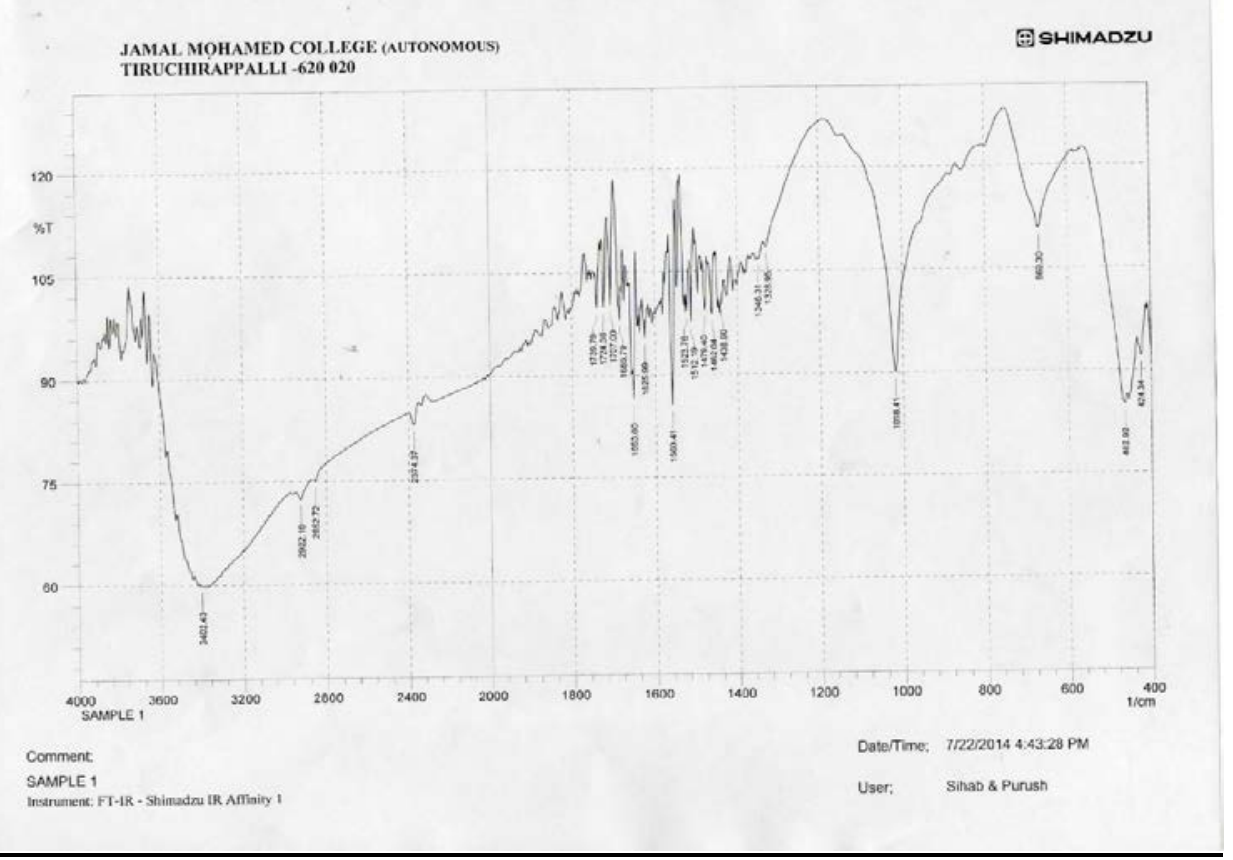

Figure 7. FT-IR Study of the control system

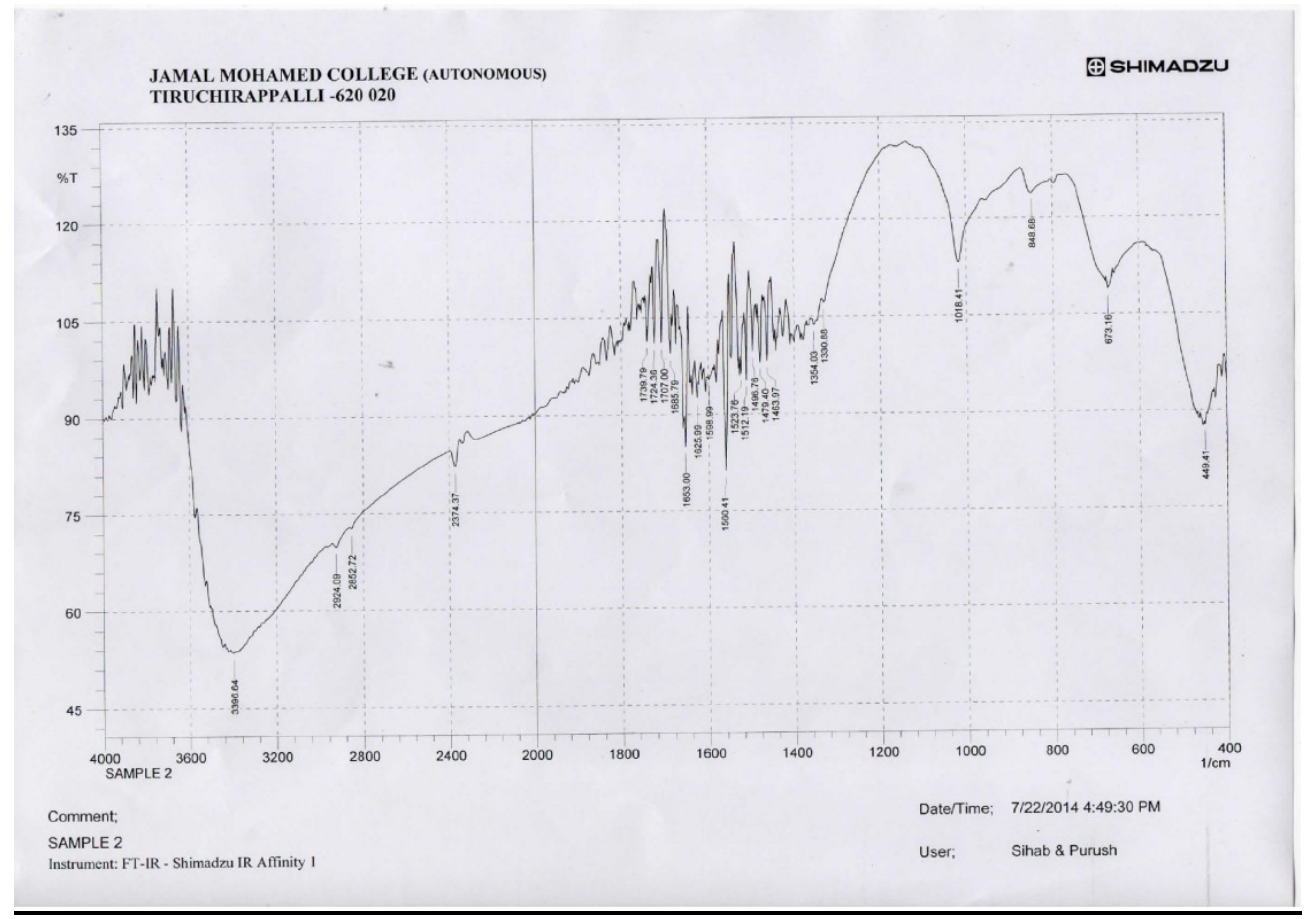

Figure 8. FT-IR Study of the control with mixed inhibitor system 


\section{Conclusion}

From the above studies conducted the following broad conclusions were drawn; the mixed inhibitors containing nitrite as one of the inhibitor maintaining the passivity even in presence of high chloride concentration of $0.5 \mathrm{M} \mathrm{NaCl}$.

The combination of nitrite ions with other inhibitors showed the synergism that enhanced the corrosion resistance performance of mild steel through repassivation, especially in the case of citrate, nitrite and benzoate mixed system.

The results obtained from gravimetric method confirm that after 30 days exposure of mild steel in control with nitrite and control with nitrite, citrate and benzoate mixed inhibitors systems showed maximum inhibition efficiency of $69 \%$ and $75 \%$. The same trend was observed for Tafel polarisation and AC impedance studies.

The FTIR spectrum report revealed the mechanism of inhibitive action. The corrosion resistance performance of these inhibitors is under synergism i.e., firstly the nitrite inhibitor oxidise the steel to $\gamma \mathrm{Fe}_{2} \mathrm{O}_{3}$ protective film formation followed by the chemisorptions of sodium benzoate and citrate over steel surface which protects the mild steel beyond $\gamma \mathrm{Fe}_{2} \mathrm{O}_{3}$ film.. From all the studies conducted only the mixed inhibitive system showed highest inhibition efficiency of mild steel in chloride contaminated concrete simulated pore solution

\section{Acknowledgement}

The authors thank the Principal of Government Arts College (Autonomous), Karur, for their support and encouragement and the authors are very much grateful to the Director of College Education, Karunya University, Cochin University, for providing analytical and spectral analysis.

\section{References}

1. Valek L, Martinez S, Serdar M and Stipanovic I, Chem Biochem Eng Qua., 2007, 21(1), 65-70.

2. Ameer M A, Fekry A M, Ghoneim A A and Attaby F A, Int J Electrochem Sci., 2010, 5, 1847-1861.

3. Florica simescu and Hassane Idrissi, Corros Sci., 2009, 51(4), 833-840; DOI: 10.1016/j.corsci.2009.01.010

4. Nahali H, Dhouibi L and Idrissi H, Constr Build Mater., 2014, 50, 87-94; DOI:10.1016/j.conbuildmat.2013.08.054

5. Abd Ei Haleem S M, Abd El Wanees S and Bahgt A, Corros Sci., 2013, 75, 1-15; DOI:10.1016/j.corsci.2013.04.049

6. Vasquez Moll D V, Salvarezza R C, Videla H A and Arvia A J, Corros Sci., 1984, 24(9), 751-767; DOI:10.1016/0010-938X(84)90025-8

7. Freire L, Nóvoa X R, Montemor M F and Carmezim M J, Mater Chem Phys., 2009, 114(2-3), 962-972; DOI:10.1016/j.matchemphys.2008.11.012

8. Abd El Haleem S M, Abd El Wanees S, Abd El Aal E E and Diab A, Corros Sci., 2010, 52(2), 292-302; DOI:10.1016/j.corsci.2009.09.004

9. Shi J J and Sun W, Cement Concrete Composites, 2014, 45, 166-175; DOI:10.1016/j.cemconcomp.2013.10.002

10. Soheila Javadian, Ali Yousefi and Jaber Neshati, Appl Surface Sci., 2013, 285(15)B, 674-681; DOI:10.1016/j.apsusc.2013.08.109

11. Sadeghi Meresht E, Shahrabi Farahani T and Neshati J, Corros Sci.,, 2012, 54, 36-44; DOI:10.1016/j.corsci.2011.08.052 
12. Pritee Pawar, Gaikawad A B and Patil P P, Sci Technol Adva Mater., 2006, 7(7), 732-744; DOI:10.1016/j.stam.2006.09.014

13. Refaey S A M, Appl Surface Sci., 2000, 157(3), 199-206; DOI:10.1016/S01694332(99)00573-5

14. Singh D D N, Rita Ghosh and Singh B K, Corros Sci., 2002, 44(8), 1713-1735; DOI:10.1016/S0010-938X(01)00179-2

15. Cabrini M, Lorenzi S and Pastore T, Electrochimica Acta, 2014, 124, 156-164; DOI:10.1016/j.electacta.2013.10.062

16. Valek L, Martinez S, Mikulić D and Brnardić I, Corros Sci., 2008, 50(9), 2705-2709; DOI:10.1016/j.corsci.2008.06.018

17. Evrim Hür, Gözen Bereket, Berrin Duran, Derya Özdemir and Yücel Şahin, Prog Orga Coat., 2007, 60(2), 153-160; DOI:10.1016/j.porgcoat.2007.07.026 